DOI 10.17150/978-5-7253-3001-4.53

И.В. КУРЫНОВА

УДК 502.5.06(571.5)(09)

ББК 40.3(253.5)г

\title{
ПРОБЛЕМА СЫПУЧИХ ПЕСКОВ В БАЙКАЛЬСКОМ РЕГИОНЕ В КОНЦЕ ХІХ - НАЧАЛЕ ХХ ВЕКА
}

На основе исторических источников анализируются причины возникновения сыпучих песков в Байкальском регионе в конце XIX - начале XX в. и рассматриваются меры, предпринятые для предотвращения их образования.

Ключевые слова: сыпучие пески, Байкальский регион, защитные леса. 


\section{PROBLEM OF DRIFT SANDS IN THE BAIKAL REGION AT THE END OF THE XIX - THE BEGINNING OF THE XX CENTURY}

On the basis of historical sources, the reasons for the occurrence of drift sands in the Baikal region in the late $\mathrm{XIX}$ - early $\mathrm{XX}$ centuries are analyzed and measures taken to prevent their formation are considered

Keywords: drift sands, Baikal region, protective forests.

Во второй половине XIX в. в результате активного промышленного развития Байкальского региона, строительства Транссибирской железной дороги, развития золотодобывающей промышленности, землеустроительных реформ значительно усилились нагрузки на лесные площади. В результате переселения крестьян из Европейской части России почти в два раза увеличилось численность населения Сибири. «В Восточной Сибири за 1896-1914 гг. осело 528,4 тыс. переселенцев, из них 127,5 тыс. в Иркутской губернии и 18,7 тыс. в Забайкалье» [3, с. 60]. Быстрый рост населения вызывал необходимость постоянного расширения площади пахотных земель. Расчистка лесов, небрежное отношение к лесам, лесные палы, самовольные рубки привели к резкому сокращению лесопокрытой площади Байкальского региона, особенно в Забайкалье. Насколько серьезным было уничтожение лесов, показывают данные, взятые из путеводителя по Сибири, изданного Центральным Статистическим Комитетом для Наследника Цесаревича. Согласно этим данным, в 1853 г. леса Забайкальской области занимали площадь в 23 млн 586 тыс. 250 десятин, а в 1884 г. осталось 5 млн 469 тыс. 200 десятин. Таким образом, за 32 года были уничтожены 18 млн 117 тыс. 50 десятин, т.е. площадь лесов сократилась более чем в 4 раза [1, с. 132].

Одним из последствий уничтожения сибирских лесов явилось появление сыпучих песков, рост оврагов, смыв гумусового слоя. В современной науке для обозначения такого рода явления применяется термин подвижные пески -поверхностные отложения чистых песков средней крупности в виде разнообразной формы холмов (дюны, барханы), передвигающихся под влиянием ветров, а в документах XIX - начала XX в. употребляются термины «сыпучие пески» или «летучие пески».

Территории Байкальского региона, в особенности степные участки Забайкалья, были предрасположены к ветровой эрозии и появлению здесь сыпучих песков в силу местных особенностей климата и почвы. В результате освоения новых земель на рубеже XIX и XX вв. пришли в движение значительные площади сыпучих песков. Они приносили большой вред местному населению - песком заносились пашни, насе- 
ленные пункты. В связи с наступлением песков приходилось даже переносить населенные пункты.

Впервые о распространении песков в Забайкалье упоминалось путешественниками XVIII в. Э. Лаксманом, П.С. Палассом и И.Г. Гмелиным. B XIX в. это явление стало предметом изучения ряда исследователей А.Н. Добромыслова, А. Яхонтова, В.А. Обручева, отмечавших серьезную проблему наличия, распространения и последствий «летучих песков». Академик В.А. Обручев по результатам геологических исследований 1895-1898 гг. констатировал фракт существования огромных площадей сыпучих песков, особенно в Троицкосавском уезде. В 1914 г. в статье «Сыпучие пески Селенгинской Даурии и необходимость их скорейшего изучения» он писал: «Оголенная песчаная площадь ... расширяется подобно язве» [7, с. 54]. В работе он отмечал: «...В настоящее время песчаная опасность (ветровая эрозия) в Селенгинской Даурии еще не велика, за исключением немногих пунктов. Но, если своевременно не будут приняты меры, то эта опасность может сделаться угрожающей... и тогда борьба с ней будет уже более трудной и гораздо более дорогой» [7, с. 54].

В 1899 г. во время поездки по Забайкальской области Главный Начальник Приамурского Края, генерал Гродеков обратил внимание на хищническое истребление лесов в долине реки Селенги, вследствие чего там повсеместно образовались сыпучие пески, угрожающие целым селениям, р. Селенге и экономическому положению всего края [6, л. 32]. В 1912-1913 гг. в Забайкалье под руководством академика Л.И. Праслова работала экспедиция Переселенческого управления, описавшая территории распространения развеваемых песков по долинам рек Хилок, Чикой, Селенга [4, с. 35].

Проблема сыпучих песков получила распространение в начале XX в. и в Иркутской губернии. Так, в 1902 г. в «Записке о сыпучих песках у г. Балаганска и прилегающей к этим пескам степи» Управляющего государственным имуществом Иркутской губернии Штромбером, направленной в Лесной Департамент сообщалось: «...Не может быть никакого сомнения, что, как балаганская степь вообще, так и прилегающие к городу пески образованы путем вырубки, постоянного вытравливания и уничтожения палами....Пески, начинаясь у самого г. Балаганска и покрывая здесь примерно 150 десятин городских земель, простираются далее вглубь степи, находящейся в пользовании инородцев» [8, л. 9].

Осознавая проблему появления сыпучих песков и их негативного влияния, власти разных уровней, предпринимали попытки для решения этого вопроса. Важная роль отводилась существующим лесничествам Иркутской губернии и Забайкальской области в плане исследования лесных пространств Байкальского региона.

Условно можно выделить несколько направлений по борьбе с сыпучими песками на рубеже XIX и XX вв. Одной из эффективных мер борь- 
бы с песками - искусственное увеличение лесопосадок на основании выработанных к этому времени приемов и методов степного лесоразведения. Для предотвращения образования сыпучих песков пустые земли Забайкальской области искусственно засаживали лесами. По имеющимся данным, эти земли на 30 лет освобождались от государственных и земских повинностей, а труды по разведению леса отмечались выплатой денежных премий, выдачей наград [9, с. 81]. Однако, не всегда власти шли на эти меры. Например в упомянутом выше деле о защите г. Балаганска от сыпучих песков на просьбу Управления государственным имуществом Иркутской губернии о необходимости обратить серьезное внимание на сохранение существующих естественных лесов путем подсадки и заращивания сыпучих песков, после длительной переписки от Лесного Департаментом в 1905 г. был получен ответ: «...укрепление летучих песков у г. Балаганска в настоящее время предпринято быть не может за отсутствием в распоряжении Лесного Департамента денежных средств, ввиду общего сокращения средств на нужды войны» $[8$, л. 13].

Другим, не менее важным направлением в деле сохранения лесов, является - изъятие лесных участков, предрасположенных к облесению, из свободного пользования. Показательно в этом отношении дело об урочищах Агицарском и по речке Мостовке в Забайкалье. Леса в этих урочищах имели экономическое и защитное значения. Урочище Агицарское располагалось на западном склоне Селенгинской долины. Под действием атмосферных осадков почва смывалась с хребтов и уносилась по падям в приречную, равнинную часть урочища, где и отлагались более крупные элементы почвы. Этому процессу были обязаны своим происхождением сыпучие пески по долине Селенги, а сама она способствовала их перемещениям [6, л. 34]. Лесные расчистки на склоне, и в верховьях реки Агицар привели к увеличению количества песков в нижней части склона, к пересыханию ключей и ручьев, образованию песчаной лощины. Лесной участок на левом берегу речки Мостовки, покрытый ценным лесом, от которого зависело существование Николаевского винокуренного завода, занимал площадь 4-5 тыс. десятин песчаной почвы. Песчаные площади, образовавшиеся после рубки леса, глубокие овраги указывали на те последствия, которые могут возникнуть после уничтожения лесного покрова. Необходимо отметить, что вышеназванные территории находились до начала 1890-х гг. в пользовании крестьян Нижне-Жиримского общества, которые категорически возражали против определения Агицарских урочищ в казенное ведомство, обострив отношения с лесничеством до крайности. Обращая внимание на важное защитное значение лесов на данной территории, верхнеудинский Лесничий в 1904 г. настоятельно ходатайствовал о сохранении в ведении лесного ведомства без права отчуждения из казны урочищ Агицары, Бурохшин, Сарамы, Зуевское по долине реки Селенги в сред- 
нем ее течении, а также урочища по реке Мостовке, выше Николаевского винокуренного завода, аргументируя это тем, что только лесничества смогут организовать правильную эксплуатацию лесов, усилить их защитное значение. «Многовековый опыт хозяйства в крестьянских лесах в Западной Европе, как и печальная участь лесонасаждений в крестьянских наделах повсеместно в России достаточно убедительно говорят против включения в крестьянские наделы лесонасаждений, которые имеют общественное значение в качестве защитных», а «частное лесовладение не может жертвовать своею прибылью ради выгод общественных», - отмечал верхнеудинский Лесничий [6, л. 33]. Управление Государственных имуществ, поддерживая его инициативу, не удовлетворило просьбу Нижне-Жиримского общества о праве бесплатного пользования пашнями и лесами для хозяйственных целей в местности Агицары, и обратилось к Старшему Чиновнику по составлению отводных записей в Забайкальской области за содействием в вопросе невозможности замежевания казенных пространств, имеющих общественное значение, в крестьянские наделы [6, л. 35].

Превентивной мерой можно считать выделение защитных лесов. Данный вопрос поднимался не только представителями лесного хозяйства, но также местной администрацией. В 1901 г. баргузинский городской староста, обеспокоенный нуждами города, обратился к военному генерал-губернатору с ходатайством, в котором предложил зачислить городские леса площадью 3000 десятин в разряд защитных, отвести городу леса такой же площади леса казенных дач, запретить рубку леса в ущельях речек Банной и Гремячей, снабжающих город питьевой водой [5, л. 27]. Управление Государственных имуществ, изучив состояние дел в баргузинских городских дачах, отметило, что «городские леса представляют собой сплошную вырубку, зарастающую молодняком, нуждающимся только в охранении и уходе» [5, л. 28]. По мнению чиновников Управления, угрозы возникновения сыпучих песков в рассматриваемой местности не было, а городское общество, на правах лесовладельца, должно само в законных пределах устанавливать правила пользования городскими лесами, оберегая защитные лесонасаждения от самовольных порубок, устанавливая специальные планы хозяйства, направленные на сохранение и возможное увеличение защитных свойств лесов определенными насаждениями. Что же касается рубки сырорастущего леса в казенной Баргузинской даче по р. Банная и р. Гремячья, то Лесничий в донесении Управлению заверил, что рубка уже запрещена в виду признания защитного значения лесов в этих местностях.

Ученый-лесовод С.П. Бонишко, исследовавший леса Забайкальской области, предлагал в разряд защитных отнести вообще все кедровые насаждения Забайкалья, установив в них правильное лесное хозяйство, ограничив лесопользование и запретив лесные расчистки [2, с. 64]. 
Таким образом, в конце XIX - начале XX в., вопрос охраны лесов и их восстановления с целью предотвращения образования сыпучих песков стал актуальным для Байкальского региона. Меры, предпринимаемые для восстановления лесов, в том числе защитных, борьба с возникновением сыпучих песков, ограничение лесопользования и т.д. не являлись в полной мере эффрективными, поскольку не были направлены на устранение причин появления сыпучих песков. Решение вопроса требовало комплексного подхода.

\section{Список использованной литературы и источников}

1. Баженова О. И. Проявление процессов опустынивания на Юге Восточной Сибири / О. И. Баженова, Е. М. Тюменцева А. А. Черкашина // Современные проблемы географии и геологии : материалы IV Всерос. науч.-практ. конфр. с междунар. участием. - Томск : Изд-во Том. гос. ун-та, 2017. - С. 131-134.

2. Бонишко С. П. Кедровый промысел в лесах Прибайкалья и Забайкалья и его перспективы в будущем / С. П. Бонишко. - Чита : Типо-литография экспедиции заготовления гос. бумаг, 1923. - 68 с.

3. Зуляр Ю. А. Очерки истории природопользования в Байкальском регионе / Ю. А. Зуляр. - Иркутск : Изд-во Иркут. гос. ун-та, 2002. - 496 с.

4. Зуляр Ю. А. Становление и развитие государственной политики борьбы с эрозией почв и опустыниванием сельскохозяйственных угодий и ее реализация в Байкальской Сибири в XX веке / Ю. А. Зуляр // Иркутский историко-экономический ежегодник: 2002. - Иркутск : Изд-во ИГЭА, 2002. — С. 35-45. Д. 19.

5. Национальный архив республики Бурятия (НАРБ). - Ф. 182. - Оп. 1. -

6. НАРБ. - Ф. 229. - Оп. 1. - Д. 28.

7. Обручев В. А. Сыпучие пески Селенгинской Даурии и необходимость их скорейшего изучения / В. А. Обручев // Труды Троицкосавско-Кяхтинского отделения Приамурского отделения Императорского РГО. - 1914. - Т. 15. - Вып. 3. C. 53-67.

8. Российский государственный исторический архив. - Ф. 387. - Оп. 8. Д. 43233.

9. Хышектуева Л. В. Историко-географические особенности землепользования в Кяхтинском районе Бурятии / Л. В Хышектуева, М. В. Алемасова // Районы Бурятии в фокусе экологических проблем Байкальского региона : материалы науч.-практ. конф. - Улан-Удэ : Изд-во Бурят. гос. ун-та, 1999. — С. 80-82.

\section{Информация об авторе}

Курышова Ирина Васильевна - кандидат исторических наук, доцент, кафедра юриспруденции, Иркутский национальный исследовательский технический университет, 664074, г. Иркутск, ул. Лермонтова, 83; e-mail: kiw09@mail.ru

\section{Author}

Irina V. Kuryshova — PhD in History, Associate Professor, Chair of Jurisprudence, Irkutsk National Research Technical University, 83 Lermontov St., 664074, Irkutsk, Russia; e-mail: kiw09@mail.ru 